\title{
Disobedience of Judges as a Problem of Legal Philosophy and Comparative Constitutionalism: A Polish Case
}

\author{
Mateusz Pilich ${ }^{1,2}$ (D)
}

Accepted: 11 January 2021 / Published online: 22 February 2021

(c) The Author(s) 2021

\begin{abstract}
The article takes up the difficult problem of the so-called disobedience of judges against the background of the experiences of the Polish departure from constitutional democracy in 2015-2020. The special role and responsibility of a judge in the state imposes restrictions on her freedom of opinion in the public sphere. Openly manifesting opposition to government policy, which in the case of an ordinary citizen is only the implementation of human rights and freedoms, may be described as controversial and contrary to applicable ethical regulations. The main thesis of this paper is the assertion that although judges who act as impartial arbitrators in disputes should generally refrain from ostentatiously opposing the actions of political authorities, they are not deprived of the possibility of protest. Also in the exercise of office, and not outside the sphere of their duties, judges should take into account overriding moral values that should be implemented by the legal order, and not the values or declarations guiding the government policies. The integrity of the judge, which prescribes restraint in statements and actions in the public sphere, as well as the care for the dignity of the office held, should not be confused with absolute subordination to the legislature or the executive, even if the judge is obliged to apply the law. The traditional attitude of the members of the judiciary, consisting in focusing only on the application of the law in individual cases and the lack of any political involvement, is being reviewed in the face of the spread of majoritarianism and the law abuse as normal techniques of exercising public authority. The disobedience of judges — although difficult to defend at first sight—may seem to be the only possible way to draw public attention to the corruption of the state system. The 'disobediant' judges can even be assigned the role of 'whistleblowers', which should help to ease their legal liability or their future rehabilitation.
\end{abstract}

Keywords Judges · Constitution · Law-abiding states $\cdot$ Rule of law $\cdot$ Public service Disobedience · Justification

\footnotetext{
"The paper is an extended version of the article published in Polish, see Wokót kryzysu praworzqdności, demokracji i praw człowieka. Księga jubileuszowa Profesora Mirosława Wyrzykowskiego, eds. A Bodnar \& A Ploszka, Warszawa: Wolters Kluwer 2020, pp. 411-433. Text published in English with the kind permission of Wolters Kluwer Polska”.
}

Extended author information available on the last page of the article 
Reverence is a virtue, but strength

Lives in established law: that must prevail.

You have made your choice,

Your death is the doing of your conscious hand.

Sophocles, Antigone ${ }^{1}$

\section{Introduction}

When in the summer of 1846 the gates of the prison in Concord, Massachusetts were closing after Henry David Thoreau, few could have imagined that the notion of 'civil disobedience' in about a hundred years would become one of the most important elements in universal philosophical and legal discourse. By refusing to pay the poll tax, Thoreau only intended to stir conscience: to make his fellow citizens aware that they thoughtlessly were giving the government the tools to wage an unfair war against neighboring Mexico and hand over fugitive slaves to the Southern states. He was not the first to fight for just law, although he may have been the first to challenge the dominant pattern of citizenship.

Explaining the reasons for his opposition, Thoreau demanded more from state officials than from average people:

The mass of men serve the State thus, not as men mainly, but as machines, with their bodies. [...] In most cases there is no free exercise whatever of the judgment or of the moral sense; but they put themselves on a level with wood and earth and stones [...]. Yet such as these even are commonly esteemed good citizens. Others, as most legislators, politicians, lawyers, ministers, and office-holders, serve the State chiefly with their heads; and, as they rarely make any moral distinctions, they are as likely to serve the devil, without intending it, as God. ${ }^{2}$

Only the refusal to obey immoral orders and laws allows a public official to continue to enjoy authority and maintain integrity:

A minority is powerless while it conforms to the majority; it is not even a minority then; but it is irresistible when it clogs by its whole [...]. This is, in fact, the definition of a peaceable revolution, if any such is possible. If the taxgatherer, or any other public officer, asks me, as one has done, 'But what shall I do?' my answer is, 'If you really wish to do anything, resign your office.' When the subject has refused allegiance, and the officer has resigned his office, then the revolution is accomplished. ${ }^{3}$

Thoreau's arguments do not give a clear answer to the question of what a representative of a state should do if she wants to fight against bad laws while still holding office. Perhaps, in the cited author's opinion, she should be 'disobedient' for the

\footnotetext{
1 Transl. by D. Fitts and R. Fitzgerald, scene 4, lines 45-48, available at https://www.fusd1.org/, p. 1096.

2 Thoreau (1849), p. 191.

3 Thoreau (1849), p. 21.
} 
sake of values - but only as a free person, not as a part of the apparatus of oppression. Yet the attitude of disobedience is no stranger to people holding public office than to average citizens. After all, this is how the act of Edward Snowden qualifies, who, by revealing controversial surveillance practices while working for the National Security Agency, undoubtedly breached the duties of an NSA officer. Some Polish judges in the era of the first Solidarity were 'disobedient', too. It was thanks to their attitude, among other things, that our society could later feel that it owed itself success in moving away from the dictatorship. ${ }^{4}$

Questions about the premises and limits of disobedience return in the era of the crisis of constitutional democracy in Central and Eastern Europe, the victim of which is a legal system based on the ideas of human dignity, individual freedom and the rule of law. ${ }^{5}$ In Poland-the biggest and, for a long time, the most successful country of the region-the true beginning of the negative trend could be drawn back to the year 2015: presidential and parliamentary elections brought full power to the coalition of three radical-right parties led by Law and Justice (Prawo $i$ Sprawiedliwość). ${ }^{6}$ Suffice it to recall that within just a couple of years, the legal landscape had changed totally. Due to court-packing and the deepening ideologisation of legal life, key institutions of the judiciary, such as the Constitutional Tribunal, the National Judiciary Council, as well as the Supreme Court have been taken over by people close to the government in terms of their affiliations and worldview. ${ }^{7}$ Attempts to counteract the building of autocratic legalism have largely failed: the last chord of the community of lawyers faithful to the principles of Western constitutionalism was the resolution of the joined Chambers of 23 January 2020, implementing the judgment of the CJEU on judicial independence. ${ }^{8}$ Swift reply from the government included, first and foremost, the so-called 'Muzzle Law' that foresees a total ban on any control of judicial nominations or of the legality of composition of the judiciary system. In this way the dissenting voices within it were to be silenced. ${ }^{9}$

\footnotetext{
${ }^{4}$ Mielczarek (2008), p. 229-231.

${ }^{5}$ In the annual Freedom House report on the state of democracy in 2019, the independence of the Polish judiciary was practically ending - the country's rating in this category reached only 1 point out of 4 possible; $c f$ Freedom House (2020), paras F1-F2. According to an earlier study, over the 2009-2018 decade, the democracy index decreased from 3.25 to 4.00 on a scale of 1 to 7 points, where 1 is a democratic regime and 7 is an undemocratic one. Despite this, in principle, Poland is still classified as "consolidated democracy"; Freedom House (2018).

6 Since then, the governing coalition 'United Right' (Zjednoczona Prawica) has had a slight majority of 235 out of 460 seats in the lower house (Sejm) during next two parliamentary terms of office; $c f$ https ://parlament2015.pkw.gov.pl/〉, 〈https://sejmsenat2019.pkw.gov.pl/sejmsenat2019/〉, visited 25 September 2020 .

7 Gersdorf and Pilich (2020), p. 10 et seq.

8 Supreme Court of Poland, Joint Chambers (2020); cf CJEU (2020).

9 Gajda-Roszczynialska and Markiewicz (2020); see esp. Article 1(19) of the Act of 20 December 2019 amending the Law on the System of Common Courts, the Act on the Supreme Court and certain other Acts (Dz. U. of 2020, item 190), which introduced the new Article 42a of the Law on the System of Common Courts that expressly prohibits the questioning of the empowerment of courts and tribunals, state constitutional bodies and law enforcement and protection authorities "in the course of the courts' activities" (including carrying out jurisdiction), as well as determining or assessing the legality of the appointment of a judge or the resulting entitlement to perform tasks in the field of justice. Applying the provisions of this act, on August 5, 2020, the Deputy Disciplinary Prosecutor of Judges of Com-
} 
The worrying prospects for the coming years encourage research on the attitudes and motivations of those holding public offices, including judges, when confronted with enormous political pressure. It is advisable to initially indicate issues that may raise doubts:

(i) The special role and responsibility of judges in the state imposes restrictions on their freedom of opinion in the public sphere. Open manifestation of opposition to the government's policy, which in the case of an ordinary citizen is only the implementation of human rights and freedoms, may be described as controversial and contrary to applicable ethical codes. ${ }^{10}$

(ii) Since 'civil disobedience', according to commonly accepted definitions, implies a demonstrative violation of applicable norms in order to influence the decision or policy of public authorities, can judges whose role is to apply the law be 'disobedient' at all? The questioning by a judge of the legal order constitutes a contradiction in the name itself and may be treated, in extreme cases, even as a criminal offense. ${ }^{11}$

The rest of the article is organized as follows. In the second part, the problem of so-called civil disobedience shall be discussed in a nutshell. Then, in the third part, similarities and differences are made between the latter and the 'disobedience' of the judges. The fourth part indicates the limitations of the public activity of the latter, which may stand in the way of the practical implementation of their dissent. The main thesis of this article is the claim that although it generally is difficult to expect from judges, acting as impartial mediators in disputes, an ostentatious opposition to the actions of political authorities, they are not deprived of the possibility of protest. Even in the exercise of their office, and not only outside the sphere of official duties, judges should take into account the overriding moral values to be implemented by the legal order, and not the values or declarations guiding government policy. If, due to lack of communication between the political branches of government and

\section{Footnote 9 (continued)}

mon Courts, judge Przemysław W. Radzik, initiated disciplinary proceedings against one of the judges of the Court of Appeal in Szczecin, claiming that the latter refused to apply the above-mentioned law in the case under examination, and by "ignoring the judgment of the Constitutional Tribunal of March 25, 2019, case No. K 12/18 [...], he took an unlawful interference in the statutory manner of appointing judges to adjudication panels"; http://rzecznik.gov.pl/wp-content/uploads/2020/08/KomunikatSzczec in.pdf. Last accessed 10 August 2020.

10 For instance, the pan-European demonstration of judges in Warsaw on 11 January 2020, entitled the "March of a Thousand Robes", was merely a peaceful expression of a negative opinion on the adoption of the law amending the law on the system of courts. And yet it was criticized in the Irish press as judges should only speak through their judgments rather than openly demonstrating their views. Several scholars from European universities launched a polemic that emphasized the importance of the struggle for common European values, including the rule of law; cf. Iustitia Polska (2020); The Irish Times (2020); Kenny (2020); McCrea (2020); Marcisz and Urbanik (2020).

11 As evidenced by one of the recent American cases, United States v. Shelley M. Richmond Joseph and Wesley MacGregor (2019): a Massachusetts judge and a court clerk were charged with obstructing a federal justice against an illegal immigrant who, thanks to their help in the course of trial, was able to avoid arrest by the Immigration and Customs Enforcement; see Barry (2019). 
the judiciary, a judge is deprived of lawful means of intervention against unlawful deeds, she may undertake reasonable steps outside her mandate. The judicial integrity, imposing restraint on statements and actions in the public sphere and care for the dignity of the office held, should not be confused with absolute subordination to the legislature or the executive, even if in general the judge is obliged to apply the law. The traditional attitude, consisting in focusing only on the application of the law in individual cases and the lack of any political involvement, is being reviewed in the face of the spread of majoritarianism and the abuse of law as normal techniques of exercising public authority. The disobedience of judges-although difficult to defend at first sight-may seem to be the only possible way to draw public attention to the corruption of the state system. The 'disobedient' judges can even be assigned the role of 'whistleblowers', which should help to ease their legal liability or to enable their future rehabilitation in spite of any current punishment.

\section{Civil Disobedience in Times of Post-Truth}

Addressing the title problem of the 'disobedience' of judges (the use of this term in quotation marks has its justification, which will be discussed in a moment) requires a brief reminder of the basic themes of the theory of civil disobedience. According to the classic definition, it is a public act, committed without violence and motivated by ethical reasons, and at the same time of political significance and contrary to the law, which was made in order to change the law or government policy. ${ }^{12}$ Like any description of a complex social phenomenon, it is unstable and under certain circumstances requires reflection and possible re-emphasis.

The first feature worth paying attention to is the public nature of the action. Civil disobedience is a kind of message not only to the government but more broadly to the public. The perpetrator does it not in secret, like a criminal, but to drag others with him. The protest should be open because it concerns the vital interest (common good) of society, local community, etc. ${ }^{13}$ It is not just a simple expression of disagreement with the government's policy, but an appeal to human conscience. ${ }^{14}$ It is not necessary to adequately warn the authorities of the intended act; an ex post declaration is sufficient. ${ }^{15}$

This feature is related to the exercise of freedom of expression, protected by both national and international law ${ }^{16}$ However, simply targeting the government or the public is not enough. Compliance with government laws and policies, even after an

\footnotetext{
12 Bedau (1961), p. 653; Rawls (1999), p. 320.

13 Bedau (1961), p. 655-656.

14 Rawls (1999), p. 321; Hoffman and Graham (2006), p. 473.

15 Smart (1991), p. 206-207.

16 In Poland see Article 54(1) of the Constitution of 1997; in Germany, cf. Article 5 of the Fundamental Law (Grundgesetz) of 1949; in France, cf. Articles 10 and 11 of the Declaration of the Rights of Man and of the Citizen of 1789; in the USA, cf. the First Amendment of 1791 to the Constitution of the United States; in the international treaty law, cf. Article 19 of the UN International Covenant on Civil and Political Rights of 1966 r., UNTS 1976, vol. 999, p. 171 (as amended); Article 10 of the European Convention on Human Rights, UNTS 1955, vol. 213, p. 221 (as amended).
} 
open protest, is usually not illegal. ${ }^{17}$ Disobedience is by definition not to be confused with various acts of expression of belief such as participating in demonstrations, making speeches, posting on social media, interviews or press releases. ${ }^{18}$ What decides is their relationship with an objectively unlawful act that is to be given proper publicity for a morally justified purpose. Only in countries where public disclosure of beliefs or opinions is criminalized does the notion of 'disobedience' take on a broader meaning.

The foregoing argument shows that an essential feature of a civil act of disobedience is its inconsistency with the law. The disobedient may directly violate either the law she is contesting or other regulations, let alone unrelated to the object of the protest, if only in this way is she able to express her dissatisfaction and persuade the authorities to change. Paradoxically, objectively unlawful measures constitute a kind of expression of 'fidelity to the law'. The act of civil disobedience is not undertaken in order to overthrow the existing legal system, but, on the contrary, to strengthen it. Had the disobedient questioned the entire legal order, their opposition would be tantamount to resistance to power (rebellion, revolution). ${ }^{19}$

Of course, in democratic law-abiding countries it may be argued that citizens have enough opportunities and channels to participate in decision-making processes to exclude justification for using such a specific method of communication with the authorities and society; ${ }^{20}$ it is generally difficult for the supporters of the legalistic conception to understand non-compliance with the law as a means to its 'better' formation or observance. ${ }^{21}$ On the other hand, it would be difficult to disagree with Hannah Arendt:

Civil disobedience arises when a significant number of citizens have become convinced that the normal channels of change no longer function, and grievances will not be heard or acted upon, or that, on the contrary, the government is about to change and has embarked upon and persists in modes of action whose legality and constitutionality are open to grave doubt. [...] In neither case can civil disobedience be equated with criminal disobedience. ${ }^{22}$

The cited description of the phenomenon quite accurately reflects the legal and political situation in countries deviating from constitutional democracy toward hybrid or authoritarian regimes. In the case of both Poland and Hungary, the public has no

\footnotetext{
17 Bedau (1991), p. 5.

18 Similarly, see Allen (1967), p. 5.

19 Kaczmarczyk (2010), p. 18.

${ }^{20}$ Cf. Molleur (1968), p. 52: "Perhaps the most fatalistic argument for contemporary civil disobedience is based on the assumption that no other means are available to obtain redress of minority grievances. Most likely those accepting this view today have done little to exhaust all possible legal avenues and resort to civil disobedience not so much out of conviction that there is no other way as the desire to obtain quicker results. It is difficult to swallow any claim that our free society is so bankrupt that no proper legal means exist for redressing grievances of minorities.".

21 According to the most representative position for this part of authors, " ... it is illicit to violate otherwise valid laws either as a symbol of protest or in the course of protest."; see Griswold (1968), p. 735; cf. also Allen (1967), pp. 16-17.

22 Arendt (1978), pp. 74-75.
} 
influence on the government's legislative policy: the legislative agenda is established at the highest level of the ruling parties and is not subject to any negotiations with stakeholders, in spite of common references to the national sovereignty, constitutional identity and the will of the people. ${ }^{23}$ This applies especially (but not exclusively) to reforming the judiciary. In the case of the Polish Constitutional Tribunal, each of a few legislative amendments leading to the takeover of the institution by persons representing circles close to the right-wing parties in 2015-16 was passed in an atmosphere of secrecy, within just a few days of the bill being submitted to parliament, always depending on the current strategy and quite detached from a profound constitutional reasoning. ${ }^{24}$ It was only due to the mass street demonstrations in July 2017 that the reform of the Polish Supreme Court, prepared at the Ministry of Justice and forced without paying attention to the protests of judges at all levels, was actually stopped.

As a consequence, the critical message of the disobedient, their idealism and the will to change policy or law in the absence of other means distinguish their act from other hypothetical situations that are subject to legal sanctions. It cannot be ruled out that the communication from the 'disobedient' who undoubtedly deliberately violate the law (even if they do not commit a crime in a moral sense) will meet the state's answer: the imposition of a penalty. ${ }^{25}$ The consent of the disobedient to the legal consequences of their actions is one of the essences of the discussed phenomenon and, in a way, proves the sincerity of their intentions. ${ }^{26}$

The problem of perceiving the disobedience of individuals from the point of view of the legal system cannot be reduced to a simple syllogism: regulations have been established providing for a penalty for violating the law - a disobedient violates the lawher conduct is punishable. There are many different ways of reacting to a breach of the law and they should be appropriate to the situation of the citizen. Legal provisions may be uncertain, in the sense that a plausible case can be made on both sides, then a citizen who follows her own judgment is not behaving unfairly. Irrespective of a possible uncertainties, in any case the government can and should not prosecute disobedient citizens when the practical reasons for doing this are relatively weak in a particular case, or can be met in other ways; the path of fairness may lie in tolerance. A man who acts of his or her own judgment of a doubtful law should not be equal to a common criminal. ${ }^{27}$

The above considerations lead us to share the thesis that civil disobedience is sometimes justified or even necessary. Since this is a kind of political participation to which everyone is entitled (the so-called liberal principle), there is hardly any justification for civil disobedience in liberal states (i.e. those recognizing the right of citizens to participate in politics), while strong reasons for undertaking such practices exist in illiberal states. Yet even in liberal states, civil disobedience can be the last resort when legal measures fail. ${ }^{28}$ Ultimately, this result is not far from Arendt's

23 Sajó and Tuovinen (2018), pp. 506, 512-513.

24 For a thorough analysis, see Sadurski (2019), p. 58 et seq.

25 Brownlee (2012) p. 19, 215.

26 Hoffman and Graham (2006), p. 473.

27 Dworkin (1968), p. 8; Dworkin (1978), p. 215.

28 Raz (1991), p. 159. 
observation: civil disobedience arises where the normal channels of political discourse cease to function.

This last conclusion is important in the post-truth era, when the alleged illegality of an opposition to unjust law is very often as easy to 'prove' as it is debatable. The impression that a certain behavior should be deemed illegal can be caused by a specific narrative in public discourse generated by politically inspired mass media; even the most absurd theses may begin to appear legitimate, if they are convenient for the rulers, thanks to the so-called 'manufacturing consent'. ${ }^{29}$ This kind of falsification of the discourse on law is conducive to both placing various acts of exercising rights and freedoms beyond the limits of normal political participation, and to punishing individuals for defending the objective legal order. Such practices considerably expand the sphere of civil disobedience.

\section{Problematic Legal Qualification of the Judges'‘Disobedience’}

How to place the so-called disobedience of judges? Let us first look at the role of the judge as a public authority holder. This is not a comfortable function. Tensions between the judiciary and other authorities are inevitable, even, and especially, in democratic countries. ${ }^{30}$ As part of judicial activities, courts have not only the right, but even the obligation to critically assess the legality of the government's actions. However, it is not true that criticizing policy or legal irregularities in case law inherently is an unacceptable political manifestation. Such actions can hardly be considered 'political' in the sense that they are part of the exercise of the judge's mandate. Moreover, courts are not even denied the right to defend the fundamental values of constitutional democracy against forces seriously violating the rules of the game, of course only within the framework of the officially sanctioned proceedings (the socalled 'militant democracy'). ${ }^{31}$

Besides, lawyers' efforts to restore the rule of law are part of their professional ethos. Some several decades ago it was already noted that a unique role of lawyers in a society results from their education and experience, which make them particularly predisposed to identify and solve legal and political problems. To be sure, the scope of judges' discretion is relatively narrow, as magistrates are obliged generally to apply the applicable law to established facts and to pass judgments in accordance

\footnotetext{
29 Herman and Chomsky (2005); generally in the context of the current American political life, see Block (2019), p. 67. In Poland, such practices have become increasingly popular ever since 2015. During the July 2017 protests against controversial court reforms, the narrative heavily depended on the broadcasters' political affiliations. While private-owned TV stations focused on events related to the reform of the judiciary as well as numerous demonstrations accompanying the work on the bill, devoting more time to this problem (ca. $70 \%$ of the time devoted to national news), it was much more neglected by the stateowned TVP (less than $50 \%$ of the country news time). Moreover, the state broadcaster showed an open hostility agaist the standpoint of both the opposition parties and judges themselves, while praising the PiS party and its allies fighting for the 'fair judiciary', allegedly in line with the Constitution; see Klepka and Ujma (2018), p. 163, 168 et seq.

30 Barak (2006), p. 215.

31 Barak (2006), p. 30.
} 
with the law. Creating law by means of precedents (in common law jurisdictions) is the maximum of the judge's ability to influence the legal system. According to the reported author, lawyers, and judges in particular, even as ordinary citizens, should rather avoid acting against the law, even if the latter were wrong. After all, they have a better chance than laymen of correcting supposedly unfair or immoral laws within the existing legal structure. Consequently, they also do not have the opportunity to resort to civil disobedience. ${ }^{32}$

The views described above do not seem entirely convincing. Firstly, it is not so clear what it actually means to decide cases 'in accordance with the law'; actually, judges have always enjoyed a wide ambit of discretion in adjudicating, which falsifies the assumption of a judge reduced to the 'mouth of the lawgiver'. Secondly, one could try to distinguish between the situation in which the lawyer acts as a public figure (in the case considered here as a judge) from that in which he acts as a citizen. If one were to assume (although this does not seem to be an acceptable thesis) the existence of the right to civil disobedience, ${ }^{33}$ then judges - when acting as citizens-would at least in theory have the right to actively oppose a government's standing as to law or policy (at least at the moral level). ${ }^{34}$ The question is, of course, whether a judge has such a right when performing her duties?

The lawyer has no simple answers to this question. Theoretically, when performing official duties (and not only closely related to adjudication) in accordance with the principle of separation of powers, a judge cannot be 'disobedient to the law', because it contradicts her systemic role. ${ }^{35}$ However, potential situations of a conflict of law and morals in the conscience of a judge may take place in various situational contexts. As part of judicial activities, a judge may, for example, face the dilemma of how to apply the law to persons showing civil disobedience. Sometimes the mere demonstration-only within the limits of constitutional decision-making gaps - of the axiological preferences of a judge who acquits the accused, withdraws from imposing a penalty or at least adopts a more lenient legal characterization of

\footnotetext{
32 Cowen (1969), pp. 595-597.

33 From a philosophical standpoint, such a right was defended i.a. by by Jürgen Habermas, who believes that "the modern constitutional state can [...] only expect of its citizens obedience to the laws if and in so far as it rests on principles worthy of recognition, in light of which that which is legal can be justified as legitimate-and, if necessary, can be rejected as illegitimate.”; Habermas (1985), p. 102.

${ }^{34}$ In practice, however, the measures used by a citizen who is a judge should be more moderate than in the case of an ordinary citizen-mainly due to the reasons related to the requirement of impartiality of the court (see below, Part 4 of the contribution).

35 Alexander Hamilton's well-known thought corresponds well with this view: "Whoever attentively considers the different departments of power must perceive, that, in a government in which they are separated from each other, the judiciary, from the nature of its functions, will always be the least dangerous to the political rights of the Constitution; because it will be least in a capacity to annoy or injure them. The Executive not only dispenses the honors, but holds the sword of the community. The legislature not only commands the purse, but prescribes the rules by which the duties and rights of every citizen are to be regulated. The judiciary, on the contrary, has no influence over either the sword or the purse; no direction either of the strength or of the wealth of the society; and can take no active resolution whatever. It may truly be said to have neither force nor will, but merely judgment; and must ultimately depend upon the aid of the executive arm even for the efficacy of its judgments."; Hamilton (2009), p. 392.
} 
an offense than the requested in the indictment, turns into a kind of 'disobedience'. This is where other authorities have put forward the expectation that the courts will not do so. ${ }^{36}$

At first glance, the 'disobedience' of a judge ${ }^{37}$ could be compared to the phenomenon of disobedience of civil servants, already discussed in the American legal literature. ${ }^{38}$ There are indeed many similarities between both, although there are also differences leading to different normative conclusions. In both cases, opposition to binding legal rules or guidelines is open and motivated by important ethical or legal principles (a kind of allegiance to the legal system). In the case of officials, disobedience is a form of breaking out of the hierarchy and acting contrary to the law, but in a broader meaning of the latter term, as it may encompass even directives and recommendations on the border of legal and political measures. The catalog of acts of official disobedience in American practice has included such acts as, for example, the refusal to implement a directive of the Department of Homeland Security ordering a halt to the deportation of immigrants by officers of the Immigration and Customs Enforcement, or the disclosure to the Congress of an internal order to classify some of the files of cases conducted by the Department of Housing and Urban Development. ${ }^{39}$ Meanwhile, judicial disobedience is undoubtedly directed at contesting law in a stricter sense, and not directly at the government's policy.

Due to acting within official functions, the justification of civil servants' disobedience lies in a blockage or disturbance of vertical communication channels, while violation of legal patterns of operation and the established hierarchy of service is the only means of restoring the legality of the administration. ${ }^{40}$ Under normal circumstances, where information and complaints can be made, it is difficult to justify a demonstrative violation of the law by an official in this way. In addition, undertaking an act of civil servants' disobedience may rely only on a sufficiently verified belief that the contested legal rules or guidelines are obviously unlawful. ${ }^{41}$

\footnotetext{
36 See the example of Mr. Sławomir Jęksa, judge of the District Court in Poznań, against whom disciplinary proceedings were initiated in connection with the content and motives of the judgment on acquitting the wife of a well-known politician of the opposition party of the charge against Article 141 of the Minor Offenses Code (indecent utterance in a public place); Jałoszewski (2019); Regional Court, Poznań (2018). Pursuant to the motives of the judgment, "the speech of the accused [...] was a negative reaction to the threat to the civil rights of social groups in the context of changes made by the current legislative and executive authorities [...] When, on the one hand, we are dealing with serious violations of the Constitution by representatives of the legislature and the executive under conditions of impunity for these actions, and on the other hand, a reaction of a citizen who opposes it in indecent words, such an act was carried out under these conditions which this Court considers to be devoid of social harm.".

37 The term 'disobedient' seems inappropriate because a judicial officer cannot be subject to the orders of others when handing down judgments, and the obligation to apply the law is something other than strictly observing it. Otherwise, judges, faced with an external attack on the legal system, would be helpless because they were forced to recognize that "law is law", even if its content is arbitrary; cf. Radbruch (2006), p. 6.

38 Nou (2019), p. 349.

39 Nou (2019), p. 357.

40 Nou (2019), pp. 367-369.

41 Including possibly also such cases where the orders and directives of superiors, which are refused by an official, violate universal shared values; zob. Nou (2019), pp. 376-378.
} 
Compared to the above phenomenon, the judge's disobedience consists of something qualitatively different. The main reason for distinguishing the 'disobedience' of officials and judges is the judge's lack of dependence on anyone's instructions regarding the content of the issued judgment. The judge is not just 'the mouth of the legislator', but the guardian of the constitution and the fundamental rights and freedoms of individuals, neither of which should be undermined by laws and regulations enacted by the elected state authorities. Hence there should be no judicial obligation to 'obey' other authorities or superiors. Within the scope of her jurisdictional function, the judge should be protected from administrative interference, both outside and inside the judicial apparatus. She may not receive vertical directives or be pressured even by other judges or persons performing administrative functions in court. ${ }^{42}$ This has been confirmed by the case law of the Polish Constitutional Tribunal:

... The judiciary, despite its isolation in terms of adjudication from other authorities, is not completely separated from them in terms of functional relations, although at the same time any external interference in their jurisdiction is constitutionally excluded. [...] Court decisions are subject to instance control only on the terms and in the forms specified in the Constitution and ordinary statue law. The consequence of this state of things is that neither the legislative nor the executive branches of government can administer justice, and therefore they cannot enter those areas where judges are independent. The final decision on the rights and obligations of individuals or organizational entities in specific cases is the exclusive competence of the judiciary. ${ }^{43}$

The judge's 'disobedience' does not therefore concern the organizational structure and the orders of superiors, but only the law. The latter, however, does not work in an axiological vacuum. Conflicts of norms belonging to various normative systems, moral, social, religious and other become inevitable. Their solution must be made in the judge's conscience. ${ }^{44}$ There are also certain political actors behind the content of 'bad' laws. Hence, of course, the judge contesting the law as it stands takes part in political discourse, by sending a message addressed to other authorities and stiring conscience; however, it is by definition not an expression of communication within the government apparatus, as in the case of disobedience by civil servants.

A conflict of conscience opens up four different possibilities for the judge to act: (i) adhere to the law; (ii) deviate from the law; (iii) disqualify (recuse) herself from the case; (iv) resign from the bench. ${ }^{45}$ The simplest option in (iv), in line with

\footnotetext{
42 European Court of Human Rights (2009), para 86; see, zob. Sillen (2019), p. 104.

43 Constitutional Tribunal (2009), with further references (omitted).

44 Zajadło (2016), p. 19, 32; Zajadło (2017), pp. 35-36.

45 Brand-Ballard (2010), p. 93. Another trial of classification of the possible solution include: (i) a blind application of the law (an escape into formalism); (ii) adjudication against the law (contra legem) but in accordance with one's conscience; (iii) the judge's resignation from the office; (iv) escaping in the socalled 'subversion' (viz. hiding a contra legem judgment behind specific arguments) or handing down a judgment that does not formally infringe the law but hides the actual motives of the decision; Zajadło J (2016), p. 32, with further references.
} 
Thoreau's argument, as well as the solution in (iii), may be an expression of the most correct behavior of a state official: the judge does not infringe the country's laws that he once promised to keep and apply by taking the oath, and at the same time does not infringe the values he considers important. ${ }^{46}$

At the level of morality, there is no simple solution. There is, to be sure, some truth in believing that as members of the state apparatus, judges can either carry out their official duties within the framework of law as it stands or step down. Is there anything in between these extremes? One might think there is indeed. A simple resignation seems to be a retreat that does not serve any just objective. ${ }^{47}$ Then if judges' acts of disobedience were to be motivated by faithfulness to superior laws (especially the country's constitution) and inner morality of law, then, in accordance with the oath, the judges should rather actively stand against injustice than wash their hands by accepting potential injustice or lawlessness (although wearing the garments of the law). ${ }^{48}$ Besides, the function of a 'whistleblower', played by a judge in society, would require the protection of acts of judicial 'disobedience', for the cost of fighting it seems to outweigh potential gains to society from such a form of activity. ${ }^{49}$ It is obvious that in times of post-truth judges sometimes are the only ones who see and understand systemic injustice of the laws enacted and an improper influence of the political authorities exerted on public opinion through traditional and electronic media.

As we have already said, situations in which a judge interprets and applies the law in a way that favors civil disobedience does not yet warrant the claim that the judge herself is disobeying the law. This type of 'disobediance' or 'objection' may consist in using discretionary power to protect the values and attitudes that contest the law, although considered correct by the judge: the judge deviates from the rules, for example, by acquitting an offender instead of finding her guilty, or refraining from imposing a penalty accordingly. Although the judge's action in such a case also has the features of a communication addressed to both the public and other authorities, it cannot generally be classified as 'disobedient', as there is no open law violation and

\footnotetext{
${ }^{46}$ The reference could be made here to a discussion once launched by Professor Raymond Wacks in his inaurugative lecture at the University of Durban in 1983. While Wacks considered the South-African legal system of the 1980s as unjust (mainly due to fundamental inequalities and repressiveness) and yet believed that judges who do not want to legitimize it should resign, his opponents took another view: judges should take advantage of the still existing decision-making gaps and the discretionary power left to them, and the withdrawal should be described as a dereliction of duty rather than a sign of moral strength; see Wacks (1984), p. 266 et seq.; cf. Dugard (1984), p. 286 et seq.; Ellmann (1997-98), p. 1047 et seq.

${ }^{47}$ Dugard (1984), pp. 293-294.

${ }^{48}$ On different consequences of the fidelity to the judicial oath, cf. Brand-Ballard (2010), p. 139 et seq.

${ }^{49}$ Similar arguments for civil servants disobedience, zob. Nou (2019), pp. 378-379. It should be clarified that in the case of judges, 'whistleblowing' does not mean just revealing abuses of power within the state administration, but rather signaling to the public the deterioration of the constitutional system and paying attention to the ever smaller space for the implementation of individual rights and freedoms. Judges see and recognize these threats best; if they are unable to communicate their observations through ordinary jurisprudence, they have every duty to announce the death of the Constitution in any other way, including the demonstrative refusal to apply unfair rights, use the mass media, etc. The price of that can be, of course, liability in law.
} 
subsequent sanctions. ${ }^{50}$ Judges usually manage to put it in within the legal framework, e.g. by evading an unfitting substantive judgment for some procedural reasons, coordinating the desired result with hierarchically higher legal principles, or the like. ${ }^{51}$ Open manifestations of discord among judicial conscience and the lawgiver's will, which amount to a forthright refusal to apply the law in a particular case (characterized as 'civil disobedience' of judges stricto sensu), belong rather to the theory from the point of view of countries where the guarantees of independence of the judiciary are respected. ${ }^{52}$

The situation is different, however, in states to which the institutions of Western constitutionalism, such as in particular the constitutional review, were transferred without reflecting on potential threats stemming from their indigenous political culture. Today, the greatest danger to the judge's role as guardian of the rights and freedoms of individuals no longer comes from the risk of an open return of totalitarian practices; it is rather misconceived legalism, a new weapon against liberal democracy. ${ }^{53}$ In parts of the globe where the rule of law has never been rooted, it is hard to find anyone who will disenchant the public from siren voices of autocratic legalism that lead Eastern European societies right behind the new Iron Curtain.

Against this background, the example of Poland is particularly illustrative. The rule of law is enshrined in the Polish Constitution (especially in Article 2), which set up a central body responsible for the constitutional review: the Constitutional Tribunal. In spite of their express competence with regard to the direct application of the Constitution as the country's supreme law (Article 8), the courts in Poland have so far preferred to abstain from carrying out the judicial review. Non-application of the enacted laws has never been treated as the routine, the more so as in cases of doubtful compliance with higher legal standards, any court could stay proceedings and submit the question of constitutionality before the Constitutional Tribunal.

Until 2015 the dialogue between the courts and the constitutional court had been evaluated as very effective; after this date, however, the state of things changed radically. ${ }^{54}$ The reason obviously was the "constitutional capture, ${ }^{55}$ undertaken by the newly elected political majority of the right-wing parties labeled as the 'United Right' with an obvious excess of constitutional powers of both the legislative and

\footnotetext{
50 Feinberg (1992), p. 152.

51 Various examples in the legal practice of common law states in the age of the fight against slavery, cf. Zajadło (2017), p. 34 et seq. On the margin of an open disobedience, one might place the recent decision of the Polish Supreme Court, in which the Polish court reforms have been questioned by the reference to the resolution of the Joint Chambers. Still the court did not allow itself to an open criticism of enacted laws but only remanded the case to be duly heard by the court seized with it; Supreme Court of Poland, Criminal Chamber (2020); cf. Supreme Court of Poland, Joint Chambers (2020).

52 Cf. Ellmann (1997-98), pp. 1051-1052.

53 See i.a. Scheppele (2018), p. 545; Drinóczi and Bień-Kacała (2019), p. 1140.

54 Pursuant to the available statistics, while in 2014, the CT received a total of 530 and in 2015-a record number of 623 cases, in 2017 the outcome dropped to 282 cases. The decrease in the number of legal questions submitted by the courts is very telling: in 2015 such cases were submitted to the Court as many as 135, and in 2017-only 21; see Szepietowska (2018), p. 19-20.

55 The term stands for a scenario of taking over the full control of the political system, without an open turnover, cf. Daly (2019), p. 21 (with further references).
} 
executive branches of government. The first and most important step was a quick subjection of the Constitutional Tribunal to the ruling coalition, partly through court-packing and legal tricks or manipulations. ${ }^{56}$

Thus the Polish judges woke up one day in a country where the usual legal discourse no longer existed. Cuius regio eius interpretatio: the government tries at all costs to impose its own interpretation of constitutional provisions, when in reality there is no independent and impartial control body ensuring the rule of law; hence it is difficult to talk about the discursive vision of law usually characterizing mature, law-abiding constitutional democracies. ${ }^{57}$ The state of things somewhat resembles pre-war Austria, where the Constitutional Tribunal likewise fell victim to the political machinations of the federal government in $1933 .{ }^{58}$ However, the Polish government was not satisfied with this decisive victory: after several years of reforms, the independence of other institutions which guarantee the status of the courts and tribunals, such as the National Council of the Judiciary in particular, has become illusory. ${ }^{59}$

The standards of the Polish Constitution have theoretically not changed in any way: judges are still independent and subject only to the Constitution and statutes. According to Article 91 of the Constitution, they are obliged to apply international treaties and EU law with priority over incompatible national laws. If the minimum independence of the judiciary were respected, it would be enough to offset the devastating consequences of the political takeover of the Constitutional Tribunal. ${ }^{60}$

Unfortunately, the role and scope of judicial independence of judges have de facto been limited so far that it is an unrealistic perspective. The most serious problem of the Polish judiciary undoubtedly is the cult of the mechanical application of legal rules. As already stated, judges are afraid of applying the Constitution directly and referring to the provisions of international treaties, ${ }^{61}$ although the current situation of course has prompted some to change their position.

However, this still happens rarely, and the price of the fight for independence can be high. Being aware of the specific habit of literal application of legal provisions, the current Polish legislature does not shy away from directly imposing on the courts the content of specific decisions in cases under consideration. Dissenting voices among the judiciary are being silenced by the politically led apparatus of repression. In this way, for example, examination of the legality of the bench was prohibited in

\footnotetext{
56 Koncewicz (2018), p. 116; Matczak (2020).

57 Gersdorf and Pilich (2020), p. 21.

58 Heller (2010), p. 251.

59 See CJEU (2020), Zoll and Wortham (2019), p. 875.

60 The example of the Netherlands is particularly suggestive here, where the Constitution-just like the Polish March 1921 Constitution before the WW2 did-not only does not provide for the institution of a constitutional court, but also expressly prohibits courts from not applying laws. This prompts the courts to extensively refer, for example, to the provisions of the European Convention on Human Rights. Despite this, the doctrine does not mention cases of prosecution of judges by the Dutch government for invoking the European Convention on Human Rights or European Union law against national laws; Corstens (2017), p. 57 et seq.

61 Krygier and Czarnota (2006), pp. 318-319.
} 
appeals against judgments, although due to the content of European case law there may be serious doubts as to the implementation of the right to a fair trial with the participation of at least some of the judges appointed in Poland as a result of defective nomination procedures. Violation of this prohibition is, in principle, subject to only one sanction: the dismissal of the judge from office by the disciplinary court. ${ }^{62}$ The fact that according to recent decisions by the EU Court of Justice in practice no system of objective disciplinary liability in Poland exists, ${ }^{63}$ proves that judges were put in a no-exit situation: between Scylla of the allegiance to the binding Constitution and Charybdis of the observance of the means adopted by the majority in parliament and the executive, which may well infringe the Constitution, while there is no possibility of verifying this hypothesis. Any opposition by the judges can be easily counteracted by simply disregarding and disqualifying the judicial role in society or using the system of repressions, which is obviously presented publicly as legal. ${ }^{64}$ Thus, in this way or another, a judge who denies the application of unjust laws in the name of the Constitution becomes 'disobedient' and is held liable in law. ${ }^{65}$

It must be repeated that the requirement of a judge's loyalty to the state is of a different nature than that of an official. Admittedly, a judge is obliged to apply generally applicable law, ${ }^{66}$ but she never does so unconditionally, viz. without control of the content of the adopted law. Consequently, the judge's obligation to apply law cannot properly be called 'obediance'; its implementation depends on the content of the legal rules in question, as well as on the legal and systemic context in which they have been located. The judge should not show indifference to these factors; she retains every right to assess whether there are still conditions allowing to fulfill her mission, as determined by the content of the oath. ${ }^{67}$ She follows enacted laws as long as it is possible to settle legal disputes in accordance with the basic requirements of independence and justice, even at the cost of legal liability.

All in all, however, it should be emphasized that the option highlighted by Professor Wacks - be silent or resign - is not the most correct reaction of a judge in the face of flagrant injustice in the legal system. By being silent, the judge behaves

\footnotetext{
62 See above, fn. 9.

63 CJEU (2020); CJEU order (GC) of 8 April 2020, C-791/19 R, Commission et al. $v$ Republic of Poland, EU:C:2020:277; Gajda-Roszczynialska and Markiewicz (2020).

64 Even the suspension by the Court of Justice of the European Union of the activities of the Disciplinary Chamber (DC) in the Supreme Court was bypassed by the government on the grounds that this body was only deprived of the right to conduct disciplinary proceedings against judges. However, according to both the government and the "new judges" at the DC, it is still possible to decide to waive the immunity of judges in order to bring criminal charges, which, in fact, is much more serious than any disciplinary means. In this way, the protective effects of the CJEU case law were disarmed by its literal and narrow interpretation; Gajda-Roszczynialska and Markiewicz (2020), p. 30; DC (2020).

65 This is precisely what some authors call the "civil disobedience" of judges; Ellmann (1997-98), pp. 1051-1052.

66 This is why I believe the term "judicial disobedience" should be enclosed in quotation marks. Indeed, it suggests functioning in opposition to unrefined legal positivism, consisting in a blind submission to enacted laws and orders, contrariwise to high standards of judicial independence and impartiality.

67 Garcia (2016), p. 237.
} 
exactly like the state agents in Thoreau's vision; ${ }^{68}$ meanwhile by giving up, she deprives herself of insight into the functioning of the state apparatus. So is there another way for the magistracy in a country that is slipping into the abyss of an 'autocratic legalism'?

\section{Judge-Citizen: Freedom of Opinion, the Right of Disobedience}

Since civil disobedience is a form of participation in the political life of a country, any form of a judge's fight for the dignity and force of law gains a strong social resonance and makes her involved - quite irrespective of the actual intentions - in politics (understood here as a discourse and not the struggle for power). Under normal circumstances, an unwritten 'non-aggression pact' between the judiciary and the political branches induces restraint on both sides: members of the judiciary express their opinions through judgments and restrict other forms of participation in public life, while other public authorities respect the status of judges and are ready to recognize and enforce judgments without questioning their content. The political disputes are then left to the representatives of political parties. A liberal state (i.e. in the sense of Joseph Raz's philosophy: one that provides citizens with a sufficiently broad framework for becoming politically engaged) does not normally confront the judge with the dilemma of whether to enter into an open public debate.

On the other hand, in a country whose authorities limit civil and political rights and freedoms, the role of too weak an opposition may be partially taken over by the courts. Citizens may perceive their case law as means to secure a stronger protection of their rights, and the opposition parties may aspire to call the courts a spokesman of their interests in disputes with the rulers. Of course, the courts do not play such a role very willingly, since they are generally aware of the systemic restrictions, as well as their relatively weak position vis-à-vis other authorities. Therefore, the judicial involvement in public matters is not direct; it is located on the margins, not in the center of political life. ${ }^{69}$

The strength of judges' resistence to the policy or law adopted in a country quite naturally correlates with restrictions imposed on them in terms of the ambit of courts' jurisdiction and, on the other hand, of the freedom of behavior in public space, including the liberty of expression of their opinion. Actions which, in the case of ordinary citizens, should not be equal to civil disobedience as such, acquire a completely different meaning in relation to judges, just because of being subject to disciplinary and even criminal sanctions linked to carrying out public office duties and responsibilities. Since the separation of the spheres of being a judge and a citizen is not entirely possible, the risk associated with taking a position or acting

\footnotetext{
68 See above, fn. 2.

69 Mustafa (2008), p. 132 (using the example of Egypt during the rule of Hosni Mubarak, he points to the role of the judiciary as a substitute for political opposition); por. Osiel (1995), p. 486 (correctly points out that in authoritarian states the courts are often a central element of a 'half-opposition', opposing certain government policies).
} 
openly in public matters allows us to believe that the concept of 'disobedience' of judges includes at least some kinds of acts which-when related to an average citizen-would qualify as legally neutral.

The existence of restrictions on the freedom of judges' participation in public life is quite obvious in states with a democratic system. However, it is difficult to say the same about the understanding of the adopted standards. For instance, the Polish Constitution of 1997 expresses this idea in Article 178(3): a judge may not belong to a political party or a trade union, or perform 'public activities incompatible with the principles of independence of the courts and judges'.

On the one hand, a ban on judges' political affiliations may be seen as natural after decades of disgraceful practices of the Polish state, where-just as in many other post-communist countries - there was a long tradition of judicial dependence, pre-dating even the post-war period. ${ }^{70}$ On the other hand, however, the notion of activities incompatible with judicial independence does not have any clear meaning in society, which of course greatly facilitates attacks against 'whistleblowers'. It is believed to correspond to at least a few specific prohibitions, including refraining from disclosure of revealing the judge's views in whatever matters of public concern which would undermine her duty of impartiality. ${ }^{71}$ Although the formula seems quite simple, its application in the event of a dispute over the fundamental values of the Polish constitutional system becomes a real problem with significance and effects far beyond the functioning of the judiciary. Can a judge belong to an association that undertakes public criticism of the laws pushed by the political leadership of the Ministry of Justice $?^{72}$ Can and should she be forced to disclose this fact to the public (if so, for what actual purpose) $?^{73}$ Least but not last, can she speak out on public matters, such as monitoring the election process $?^{74}$ Such questions are by no means idle theorizing in a country that belongs to the Council of Europe and thus it

\footnotetext{
$\overline{{ }^{70} \text { Krygier and Czarnota (2006) }}$, pp. 314-315. Certainly, judges in Poland as the whole have never immediately been lenient towards authoritarian governments. However, in a more or less undemocratic political system, there had to be instruments of political pressure, and true independence was unimaginable. In the times of the People's Republic of Poland, any Polish judge could be removed from office by a resolution of the State Council on the grounds of his or her "lack of guarantee of the proper performance of judicial duties." Thus, for instance, in the wake of the repression accompanying the martial law in February 1982, the Minister of Justice asked the State Council to dismiss 18 judges known from the activities of the Solidarity trade union. All applications were approved as soon as they were received by the latter authority; see Niewiński (2016), pp. 211 et seq.

71 Śladkowski (2014), p. 219 (with further references); cf. i.a. Constitutional Tribunal (1993).

${ }^{72}$ Several judges' associations currently gather approx. $40 \%$ of their total population (viz. 4,000 in 10,000 altogether). The biggest of them, Polish Judges' Association "Iustitia" (Stowarzyszenie Sędziów Polskich "Iustitia", reporting ca. 3,500 members), is at the same time the most seriously involved in public criticism of the controversial judiciary reforms; cf. https://www.iustitia.pl/en/activity/opinions (last visited: 20/08/2020).

${ }^{73}$ See Article 1(29) of the Act of 20 December 2019 (supra, fn. 9)-the so-called "Muzzle Law": the new Article 88a of the Law imposes an obligation of judge's written statements revealing their membership in any organization, incl. associations (irrespective of the nature of their activities).

${ }^{74}$ According to the press releases, even 1,200 Polish judges may be charged with a disciplinary offense because of signing an open letter to the OSCE-ODIHR calling for the monitoring of the last Polish presidential elections; Onet (2020).
} 
should tolerate judges' freedom of opinion and association, while at the same time it adopts legislation to remove magistrates as a disciplinary means for violating the requirement of 'political neutrality', understood in line with the wishes of the current government.

To be sure, the specific requirements for judges as participants in public life do not occur only in Poland. For instance, Canon 5 of the Code of Conduct for United States Judges prohibits the addressees from holding office in political organizations, publicly speaking out for or against political organizations or candidates, and financially supporting them. A federal judge is considered to entertain her personal views of political questions, but should not directly nor indirectly participate in partisan political activities; the judicial office necessarily imposes restrictions on the exercise of certain political freedoms. ${ }^{75}$ Moreover, judges as 'government employees' do not enjoy the normal First Amendment guarantees of the US Constitution and their involvement in criticizing the law or in changing the legal system or principles can only take place within the judicial system and not through public speaking. Nevertheless, courts are rather reluctant to accept judges' liability for speaking their opinions, pointing out, inter alia, to the fact that the judge is also a citizen. ${ }^{76}$ The legal situation of both federal and state courts' judges when speaking publicly in the US is still far from clear, although the restrictions imposed on them, especially as a result of the ruling of the US Supreme Court in the case of Republican Party of Minnesota $v$. White, ${ }^{77}$ practically are not too severe. It seems that statements by judges on topics of interest to the general public, also in matters of the federal or state policies, are not uncommon. ${ }^{78}$

When it comes to French law, an example is willingly cited in Poland in connection with the so-called 'Muzzle Law' of 20 December 2019, so deeply interfering with judicial independence, ${ }^{79}$ judges admittedly are forbidden from 'demonstrating hostility to the principles of operation or form of the Republic's government', as well as 'any political statements' ${ }^{80}$ However, official opinions emphasize that only abusive or deliberately provocative comments are subject to sanctions, as well as such statements as may undermine the obligation of judicial impartiality. It is not forbidden to hold or express political opinions as such, or even to be a member or a candidate for a political party. Moreover, in the opinion of the French Supreme Council of the Judiciary in 1987 , it was stated that 'the duty of restraint must not

\footnotetext{
75 Guide to Judiciary Policy, vol. 28, Ch. 2, https://www.uscourts.gov/sites/default/files/guide-vol02 b-ch02-2019_final.pdf, pp. 21-22.

76 Smolla (2014), pp. 976-978 (with further references); cf. esp. Washington S.C. in re Sanders, 955 P.2d 369, 375 (Wash. 1998): "A judge does not surrender First Amendment rights upon becoming a member of the judiciary.".

77536 US 765 (2002).

78 See Geyh (2011), p. 266 et seq.

79 Cited supra, fn. 9.

${ }^{80}$ See Article10 of the Order No. 58-1270 of 22 December 1958 on the organic law on the status of judges (Ordonnance $n^{\circ} 58-1270$ du 22 décembre 1958 portant loi organique relative au statut de la magistrature), t. jedn.: https://www.legifrance.gouv.fr/affichTexte.do?cidTexte=JORFTEXT0000003 39259. Last accessed: 10 August 2020.
} 
serve to reduce the magistrate to silence or conformism, but must be reconciled with the particular right to independence which fundamentally distinguishes the magistrate from the civil servants' ${ }^{81}$

Interesting conclusions can be drawn from this short review for current Polish practice. First of all, it should be noted that the 'black letters' of the provisions regulating the public status and responsibility of judges in various countries sometimes differ quite far from their application. Hence, there is a huge risk related to the transfer of these provisions to the states where-as is the case in Poland-an insufficiently developed political culture is not conducive to maintaining the separation of powers. In mature constitutional democracies, the judge is silent outside the courtroom not because he is not allowed to speak out, but because he does not have to stir the conscience of her fellow citizens and members of the political class. Codes of ethics confirm the status quo rather than silence the judge. The moderation of each of the branches of government results from an internalized belief that they each have limits of their influence, the crossing of which will meet with appropriate social counteraction.

In young and unconsolidated democracies the measure of the lawfulness of a judge's conduct in public space must be different, just like the conditions in which the statehood is being shaped still differ from the Western models. Although in this case the holder of the judicial authority is bound by moderation and prudence in preaching her moral convictions and showing faithfulness to them, the lack or disregard of the established standards of conduct on the part of the elected authorities undermines the thesis that judges whose mandate too comes from the nation should publicly stay silent in the face of lowering or abandoning constitutional rules. It is no one's duty to endure lawlessness. As citizens, judges retain the right to oppose a government that violates a social contract: the constitution. After all, they do not lose the inherent human dignity and freedom, also in terms of interpersonal relations in the public space. And moreover, as 'whistleblowers' they truly can understand misconceived practices of the 'political' authorities and aware the public of their possible consequences for the future. This role of judges deserves moral-as well as legal-protection.

Suming up, Thoreau's thesis quoted at the beginning of this essay is correct: a judge inactive in the face of an obvious failure of the government to uphold the highest rights does not even deserve her own respect. Yet his claiming that a social bloodless revolution requires judges, like other state agents, to step down on their own when facing injustice seems to be principally wrong.

\section{Closing Remarks}

Judges should obey the law and express themselves through their judgments. Generally, this is what we expect from them. In modern, law-abiding representative democracies, the belief that the power to judge is separate from lawmaking and law

81 Platon (2020). 
enforcement is taken for granted. The role of the courts is not to fight the government and parliament: both because of their credibility as conciliators and because they do not have a direct democratic mandate. As part of their public function, judges do not have the means or powers to actively influence the course of public affairs outside the courtroom. Limiting the courts by law is inherent in the essence of co-creating the state apparatus. Entrance into the domain of other authorities is as feared as in any other case. Any too active branch of the government can easily turn despotic. $^{82}$

Sanctioning (or at least attempting to sanction) the acts of judges that consist in expressing in the public space opinions that undermine government reforms, such as e.g. changing the composition of the Polish National Council of the Judiciary or the establishment of the Disciplinary Chamber of the Supreme Court, undoubtedly qualifies this type of behavior of the Polish judges as sui generis 'disobediance'. In the world of post-truth, in which political authorities follow the rule 'cuius regio eius interpretatio', the actual compliance or non-compliance of such conduct with the constitution or international law is of little social importance. Appropriation of full authority fosters the criminalization of public opinion-making and moves the boundaries of judicial 'disobedience' very far outside the courtroom.

Can a judge disobey and how? One can agree with the thesis that the role of 'reviewers' of social or political life does not fall within the scope of the constitutional competences of judges. ${ }^{83}$ But let us look at it on the other side of the coin: do we not expect more from judges than from other state officers? Do we want them to be obedient conformists, or maybe 'whistleblowers' and guardians of the legal order?

If the latter is true, then the judge may not be bound to stay inactive out of the courtroom. Quite contrariwise: her duty should be to weight out what best serves the society. In Polish private law (Articles $142 \& 424$ of the Civil Code ${ }^{84}$ ) and criminal law (Article 26 of the Criminal Code ${ }^{85}$ ) there exists an institution of the 'state of

\footnotetext{
82 Cf. Thomas Jefferson's view in his letter to Abigail Adams of 11/09/1804: „The opinion which gives to the judges the right to decide what laws are constitutional and what not, not only for themselves, in their own sphere of action, but for the Legislature and Executive also in their spheres, would make the Judiciary a despotic branch."; Wolfe (1994), p. 94. Although not a generalized statement, the passage quoted above seems to reflect the skeptical attitude of the third US president towards the political position of judges. In another letter of 23/05/1807 to John W. Eppes, Jefferson openly lamented the power of the American judiciary, writing about "the original error [in] establishing a judiciary independent of the nation, [...] which, from the citadel of the law, can turn its guns on those they were meant to defend, and control and fashion their proceedings to its own will."; https://founders.archives.gov/documents/Jeffe rson/99-01-02-5646. Last accessed: 4 February 2020.

83 Śladkowski (2014), p. 222.

84 Cf. Article 142(1), first sentence, of the Civil Code: An owner cannot object to the use and even damage or destruction of a thing by another person if it is necessary to avert danger directly threatening the personal interests of that person or a third party [...]. Article 424 of the Civil Code: Anyone who destroys or damages another person's thing or kills or wounds an animal belonging to another person in order to avert danger threatening directly from the thing or animal to himself or to other persons is not liable for resulting damage if he did not cause the danger himself and the danger could not have been otherwise prevented and if the interest saved is obviously more important than the interest violated.

85 Cf. Article 26(1) of the Criminal Code of Poland: Anyone whose actions are carried out in order to avert an immediate danger threatening any legally protected interest, if the danger cannot otherwise be avoided and the interest sacrificed is less valuable than the interest saved, is not deemed to have committed an offence.
} 
need' (well known also to the law of many other countries). It removes the unlawfulness of an act that is undertaken to protect a value higher than that which has been infringed. Faced with an internal attack on the legal system-involving an attempted constitutional takeover-the same logic should apply to constitutional law. ${ }^{86}$ By the same token, judges are not obliged to remain 'apolitical' when facing an actual abandonment of an objective constitutional review and de facto changing the state system without amending the Constitution by the current governing majority. When holding office, under the provisions of Article 178(1) of the Constitution, they have every right to assign to the Constitution and its protection a value higher than the implementation of the Acts of parliament, even for the temporary price of a disciplinary penalty or criminal sanctions.

In the face of a state of constitutional need, a judge is not obliged to stay passive. Admittedly, in the case Wille v. Liechtenstein the European Court of Human Rights noticed that '...it can be expected of public officials serving in the judiciary that they should show restraint in exercising their freedom of expression in all cases where the authority and impartiality of the judiciary are likely to be called in question'. ${ }^{87}$ In later case law, however, the role of judges' opinions in the democratic society was equally strongly emphasized:

...Having regard in particular to the growing importance attached to the separation of powers and the importance of safeguarding the independence of the judiciary, any interference with the freedom of expression of a judge in a position such as the applicant's calls for close scrutiny on the part of the Court $[\ldots]$. Furthermore, questions concerning the functioning of the justice system fall within the public interest, the debate of which generally enjoys a high degree of protection under Article 10 [...]. Even if an issue under debate has political implications, this is not in itself sufficient to prevent a judge from making a statement on the matter [...]. Issues relating to the separation of powers can involve very important matters in a democratic society which the public has a legitimate interest in being informed about and which fall within the scope of political debate. ${ }^{88}$

It is interesting that even in Great Britain, which probably was the first country in the world to explicitly formulate in its constitutional law guarantees of judicial independence, Sir John Thomas (until 2017 Lord Chief Justice of England and Wales) made an intriguing declaration from the Polish point of view: judges should become politically involved if it is necessary to maintain the rule of law (sic!). In a speech on 'judicial independence in a changing constitutional landscape' Lord Justice Thomas proposed an end to the isolation of judges from political reality and encouraged a 'more proactive attitude of the judiciary', besides in this case inspired by an idea of cooperation rather than confrontation with the government. ${ }^{89}$ All in

\footnotetext{
${ }^{86}$ In the context of the Polish constitutional case law, see Małecki and Pach (2018), p. 38.

87 ECHR (2009), para 64.

88 ECHR (2016), para 165.

89 Bowcott (2015).
} 
all, such a declaration clearly goes beyond the limits of the Western European paradigm of political neutrality of the judiciary. Perhaps it heralds deeper changes in the attitude of neutrality and public disengagement of judges. Provocative as they might appear, such changes may appear necessary in the interests of the future of constitutional democracy. Defending the constitution and the independence of the judiciary enshrined in it, also in a non-judicial way, even by demonstrative violation of the enacted statutory law, may turn out to be justified if other channels of communication with the legislative and the executive powers are closed. The independence of the courts and judges can be costly, ${ }^{90}$ but striving for it is always necessary if the courts are to maintain the mandate of public trust.

Open Access This article is licensed under a Creative Commons Attribution 4.0 International License, which permits use, sharing, adaptation, distribution and reproduction in any medium or format, as long as you give appropriate credit to the original author(s) and the source, provide a link to the Creative Commons licence, and indicate if changes were made. The images or other third party material in this article are included in the article's Creative Commons licence, unless indicated otherwise in a credit line to the material. If material is not included in the article's Creative Commons licence and your intended use is not permitted by statutory regulation or exceeds the permitted use, you will need to obtain permission directly from the copyright holder. To view a copy of this licence, visit http://creativecommons.org/licen ses/by/4.0/.

\section{References}

Allen, F. A. 1967. Civil Disobedience and the Legal Order (Part I). University of Cincinnati Law Review 36: $1-38$.

Arendt, H. 1978. Crises of the Republic. San Diego, CA: Harcourt Brace and Company.

Barak, A. 2006. The judge in a democracy. Princeton, NJ: Princeton University Press.

Barry, E. 2019. When the judge became the defendant. New York Times, 16 November 2019. https://www. nytimes.com/2019/11/16/us/shelley-joseph-immigration-judge.html. Accessed 13 July 2020.

Bedau, H. A. 1961. On Civil Disobedience. Journal of Philosophy 58: 653-665.

Bedau, H. A. 1991. Introduction. In Civil Disobedience in Focus, ed. H.A. Bedau, 1-12. London: Routledge.

Block, D. 2019. Post-Truth and Political Discourse. Cham: Palgrave Macmillan.

Bowcott, O. 2015. Judges must engage in politics to preserve rule of law-Lord Chief Justice. The Guardian, 17 September 2015, https://www.theguardian.com/law/2015/sep/17/judges-engage-polit ics-preserve-rule-law-lord-chief-justice. Accessed 10 Aug 2020.

Brand-Ballard, J. 2010. Limits of Legality: The Ethics of Lawless Judging. Oxford: Oxford University Press.

Brownlee, K. 2012. Conscience and Conviction: The Case for Civil Disobedience. Oxford: Oxford University Press.

CJEU. 2020. CJEU judgment of 19 November 2019, Joined Cases C-585/18, C-624/18 and C-625/18, A.K. and others, ECLI:EU:C:2019:982

Constitutional Tribunal. 1993. Judgment of 9 November 1993, case No. K 11/93. Orzecznictwo Trybunału Konstytucyjnego-Zbiór Urzędowy. 1993/2/37

Constitutional Tribunal. 2009. Judgment of 15 January 2009, case No. K 45/07. Orzecznictwo Trybunału Konstytucyjnego-Zbiór Urzędowy. 2009/1A/3

Clifford Wallace, J. 2001. An Essay on Independence of the Judiciary: Independence from What and Why. NYU Annual Survey of American Law 58: 241-258.

${ }_{90}$ Clifford Wallace (2001), p. 244-246. 
Corstens, G. 2017. Understanding the Rule of Law. Oxford-Portland: Hart Publishing.

Cowen, L. 1969. The Lawyer's Role in Civil Disobedience. North Carolina Law Review 47: 587-597.

Daly, T. G. 2019. Democratic Decay: Conceptualising an Emerging Research Field. Hague Journal on the Rule of Law 11: 9-36.

DC. 2020. Supreme Court-Disciplinary Chamber, Decision of 23 September 2020, II DO 52/20. http:// www.sn.pl/aktualnosci/SiteAssets/Lists/Komunikaty_o_sprawach/AllItems/Case\%20II\%20DO\%20 52-20.pdf (English). Accessed 17 Nov 2020.

Drinóczi, T., and A. Bień-Kacała. 2019. Illiberal Constitutionalism: The Case of Hungary and Poland. German Law Journal 20: 1140-1166.

Dugard, J. 1984. Should Judges Resign?-A Reply to Professor Wacks. South African Law Journal 101: 286-294.

Dworkin R. 1968. On not prosecuting civil disobedience. New York Review of Books, 6 June 1968. http:// people.brandeis.edu/ teuber/On_Not_Prosecuting_Civil_Disobedience_by_Ronald_Dworkin.pdf. Acceded 15 July 2020.

Dworkin, R. 1978. Taking Rights Seriously. Cambridge, MA: Harvard University Press.

Ellmann S. 1997-98. To Resign or Not to Resign? Cardozo Law Review 19:1047-1059

European Court of Human Rights. 1999. Judgment of 28 October 1999. Wille v. Liechtenstein, appl. No. 28396/95. CE:ECHR:1999:1028JUD002839695. http://hudoc.echr.coe.int/eng?i=001-58338. Accessed 20 Aug 2020.

European Court of Human Rights. 2009. Judgment of 22 December 2009. Parlov-Tkalčić v. Croatia, appl. No. 24810/06. CE:ECHR:2009:1222JUD002481006. http://hudoc.echr.coe.int/fre?i=00196426. Accessed 20 Aug 2020.

European Court of Human Rights. 2016. Judgment of 23 June 2016. Baka v. Hungary, appl. No. 20261/12. CE:ECHR:2016:0623JUD002026112. http://hudoc.echr.coe.int/fre?i=001-163113. Accessed 20 Aug 2020.

Feinberg, J. 1992. Freedom and Fulfilment: Philosophical Essays. Princeton, NJ: Princeton University Press.

Freedom House. 2018. Nations in Transit Ratings and Averaged Scores 2018: Poland. https://freedomhou se.org/country/poland/nations-transit/2018.

Freedom House. 2020. Freedom in the World 2020: Poland. https://freedomhouse.org/country/poland/ freedom-world/2020.

Gajda-Roszczynialska, K., and K. Markiewicz. 2020. Disciplinary Proceedings as an Instrument for Breaking the Rule of Law in Poland. Hague Journal on the Rule Law. https://doi.org/10.1007/s4080 3-020-00146-y.

Garcia, M. 2016. Du juge « bouche de la loi » dans sa «tour d'ivoire » au juge « gardien des promesses » dans la cité: une reformulation contemporaine de l'indépendance judiciaire/From the Judge as 'Mouth of the Law' in His 'Ivory Tower' to the Judge as 'Guardian of Promises' in the City: A Contemporary Reformulation of Judicial Independence. Canadian Criminal Law Review 21: 237-267.

Gersdorf, M., and M. Pilich. 2020. Judges and Representatives of the People: A Polish Perspective. European Constitutional Law Review 16: 1-34. https://doi.org/10.1017/S1574019620000206.

Geyh, C. G. 2011. The Criticism and Speech of Judges in the United States. In Judiciaries in Comparative Perspective, ed. H. Lee, 257-275. Cambridge: Cambridge University Press.

Griswold, E. N. 1968. Dissent-1968. Tulane Law Review 42: 726-739.

Habermas, J. 1985. Civil Disobedience: Litmus Test for the Democratic Constitutional State. Berkeley Journal of Sociology 30: 95-116.

Hamilton, A. 2009. The Federalist No. 78: The Judiciary Department. In The Federalist Papers by Alexander Hamilton, James Madison, and John Jay, ed. I. Shapiro. New Haven, CT: Yale University Press.

Heller, K. 2010. Der Verfassungsgerichtshof: Die Entwicklung der Verfassungsgerichtsbarkeit in Österreich von den Anfängen bis zur Gegenwart. Wien: Verlag Österreich.

Herman, E. S., and N. Chomsky. 2005. Manufacturing Consent. New York: Pantheon.

Hoffman, J., and P. Graham. 2006. Introduction to Political Theory. Harlow: Pearson Education.

Jałoszewski, M. 2019. To już inkwizycja. Rzecznik dyscyplinarny ściga... rzecznika dyscyplinarnego. https://archiwumosiatynskiego.pl/wpis-w-debacie/to-juz-inkwizycja-rzecznik-dyscyplinarny-sciga -rzecznika-dyscyplinarnego/.

Kenny, D. 2020. Judges protesting in Poland, 11/01/2020. https://www.irishtimes.com/opinion/letters/ judges-protesting-in-poland-1.4136143. Accessed 10 Aug 2020. 
Klepka, R., and M. Ujma. 2018. Protests against judicial reform in Poland in evening news programs: Media creation of events. In Trendy przestrzeni międzynarodowej w wymiarze globalnym i regionalnym, vol. 2, ed. A. Kordonska, et al., 163-175. Lviv: Ivan Franko National University of Lviv.

Koncewicz, T.T. 2018. The Capture of the Polish Constitutional Tribunal and Beyond: Of Institution(s), Fidelities and the Rule of Law in Flux. Review of Central and East European Law 43: 116-173.

Krygier, M., and A. Czarnota. 2006. After Postcommunism: The Next Phase. Annual Review of Law and Social Science 2: 299-340. https://doi.org/10.1146/annurev.lawsocsci.2.081805.105756.

Małecki and Pach. 2018. Stan wyższej konieczności konstytucyjnej. Państwo i Prawo 7:38-57

Marcisz, P., and J. Urbanik. 2020. Judges and protests in Poland, 14/01/2020. https://www.irishtimes .com/opinion/letters/judges-and-protests-in-poland-1.4138384. Accessed 10 Aug 2020.

Matczak, M. 2020. The Clash of Powers in Poland's Rule of Law Crisis: Tools of Attack and SelfDefense. Hague Journal on the Rule of Law. https://doi.org/10.1007/s40803-020-00144-0.

McCrea, R. 2020. Irish judges have every right to back protests in Poland. https://www.irishtimes.com/ opinion/irish-judges-have-every-right-to-back-protests-in-poland-1.4142089. Accessed 10 Aug 2020.

Mielczarek, A. 2008. Lost Capital: The Intelligentsia Current of Underground 'Solidarity' in Free Poland. Polish Sociological Review 163: 229-244.

Molleur, R. R. 1968. A House Divided Against Itself: The Threat of Contemporary Civil Disobedience to the American Legal System. Catholic University Law Review 18: 37-53.

Mustafa, T. 2008. Law and Resistance in Authoritarian States: The Judicialization of Politics in Egypt. In Rule by Law: The Politics of Courts in Authoritarian Regimes, ed. T. Ginsburg and T. Mustafa, 132-155. Cambridge: Oxford University Press.

Niewiński, K. 2016. PZPR a sqdownictwo w latach 1980-1985. Próby powstrzymania. solidarnościowej rewolucji. Bialystok: $\mathrm{PhD}$ diss. https://repozytorium.uwb.edu.pl/jspui/bitstream/11320/5435/1/ PZPR\%20a\%20S\%C4\%85downictwo\%20w\%201atach\%201980-1985.\%20Pr\%C3\%B3by\%20pow strzymania\%20solidarno\%C5\%9Bciowej\%20rewolucji.pdf. Accessed 23 Nov 2020.

Nou, J. 2019. Civil Servant Disobedience. Chicago-Kent Law Review 94: 349-381.

Onet. 2020. Będzie 1,2 tys. dyscyplinarek? Sędzia chce karać za podpisanie listu do OBWE. https:// wiadomosci.onet.pl/kraj/apel-sedziow-do-obwe-sedzia-przemyslaw-radzik-interweniuje/p27v1 mp. Accessed 20 Aug 2020.

Osiel, M.J. 1995. Dialogue with Dictators: Judicial Resistance in Argentina and Brazil. Law \& Social Inquiry 20: 481-560. https://doi.org/10.1111/j.1747-4469.1995.tb01069.x.

Platon, S. 2020. French Law is NOT a Model for the Polish Bill on Disciplining Judges. VerfBlog. https:// doi.org/10.17176/20200120-124637-0.

Radbruch, G. 2006. Statutory Lawlessness and Supra-Statutory Law. Oxford Journal of Legal Studies 26: $1-11$.

Rawls, J. 1999. A Theory of Justice. Revised edn. Cambridge, MA: Harvard University Press.

Raz, J. 1991. Civil Disobedience. In Civil Disobedience in Focus, ed. H. A. Bedau, 159-169. London: Routledge.

Regional Court, Poznań. 2018. Judgment of 24 September 2018, case No. IV Ka 818/18. http://orzec zenia.poznan.so.gov.pl/content/\$N/153510000002006_IV_Ka_000818_2018_Uz_2018-10-10_001. Accessed 10 Aug 2020.

Sadurski, W. 2019. Poland's Constitutional Breakdown. Oxford: OUP.

Sajó, A., and J. Tuovinen. 2018. The Rule of Law and Legitimacy in Emerging Illiberal Democracies. Osteuropa Recht 64 (4): 506-529.

Scheppele, K. L. 2018. Autocratic Legalism. The University of Chicago Law Review 85: 545-583.

Sillen, J. 2019. The Concept of 'Internal Judicial Independence' in the Case Law of the European Court of Human Rights. European Constitutional Law Review 15: 104-133. https://doi.org/10.1017/S1574 019619000014.

Smart, B. 1991. Defining Civil Disobedience. In Civil Disobedience in Focus, ed. H. A. Bedau, 189-211. London: Routledge.

Smolla, R. A. 2014. Regulating the Speech of Judges and Lawyers: The First Amendment and the Soul of the Profession. Florida Law Review 66: 961-990.

Supreme Court of Poland-Criminal Chambers. 2020. Decision of 25 June 2020, Case No. I KZP 1/20, Orzecznictwo Sądu Najwyższego Izba Karna. 26 July 2020.

Supreme Court of Poland-Joint Chambers. 2020. Resolution of Civil, Criminal, and Labor and Social Security Chambers of 23 January 2020, Case No. BSA I-4110-1/20. Orzecznictwo Sądu Najwyższego Izba Karna. 2020/2/7. 
Szepietowska, B. 2018. Działalność orzecznicza Trybunału Konstytucyjnego w latach 2014-2017. In Funkcjonowanie Trybunatu Konstytucyjnego w latach 2014-2017, 15-56. Warszawa: Fundacja Batorego.

Śladkowski, M. 2014. Granice swobody wypowiedzi sędziego w świetle Konstytucji RP. In Wolność wypowiedzi i jej granice: analiza wybranych zagadnień, ed. A. Biłgorajski, 209-222. Katowice: Wydawnictwo Uniwersytetu Śląskiego.

Thoreau, H. D. 1849. Resistance to Civil Government. In Aesthetic Papers, ed. E. P. Peabody, 189-211. Boston: The Editor.

The Irish Times. 2020. The Irish Times view on Irish judges protesting in Poland: crossing a line. https://www.irishtimes.com/opinion/editorial/the-irish-times-view-on-irish-judges-protesting -in-poland-crossing-a-line-1.4134097?fbclid=IwAR1 AdLY7DT7q6x4BE0KbmB_leS7XqTdM6 L31O_2IZOXhOeWUP4gCOx_Iks4. Last accessed 10 Aug 2020.

Wacks, R. 1984. Judges and Injustice. South African Law Journal 101: 266-285.

Wolfe, C. 1994. The Rise of Modern Judicial Review: From Constitutional Interpretation to Judge-Made Law. New York: Basic Books.

Zajadło, J. 2016. Nieposłuszeństwo Sędziowskie. Państwo i Prawo 71 (1): 18-39.

Zajadło, J. 2017. Sumienie Sędziego. Ruch Prawniczy, Ekonomiczny i Socjologiczny 79: 31-41.

Zoll, F., and L. Wortham. 2019. Judicial Independence and Accountability: Withstanding Political Stress in Poland. Fordham International Law Journal 42: 875-948.

Publisher's Note Springer Nature remains neutral with regard to jurisdictional claims in published maps and institutional affiliations.

\section{Authors and Affiliations}

\section{Mateusz Pilich ${ }^{1,2}$}

$\triangle$ Mateusz Pilich

m.pilich@wpia.uw.edu.pl

1 Faculty of Law, University of Warsaw, Warsaw, Poland

2 Office for Studies and Analyses of the Supreme Court of the Republic of Poland, Warsaw, Poland 